\title{
Respecting the Authors by Journals' Editorial Team: Doing a Favor or a Responsibility?
}

\author{
Shakiba Seifi ${ }^{10}$, Amir Human Hoveidaei2,3 (D), Amin Nakhostin-Ansari 4,5 (D) \\ ${ }^{1}$ Faculty of Medicine, Najafabad Branch, Islamic Azad University, Najafabad, Iran \\ ${ }^{2}$ Student Research Committee, Shiraz University of Medical Sciences, Shiraz, Iran \\ ${ }^{3}$ Students Scientific Research Center, Tehran University of Medical Sciences, Tehran, Iran \\ ${ }^{4}$ Sports Medicine Research Center, Neuroscience Institute, Tehran University of Medical Sciences, Tehran, Iran \\ ${ }^{5}$ Research Center for War-affected People, Tehran University of Medical Sciences, Tehran, Iran
}

To the Editor,

Ethical concepts are one of the fundamental aspects of research projects. Most journals emphasize these ethical roles. ${ }^{1}$ However, another aspect of ethics in research that is related to editors' and journals' responsibilities is somehow neglected compared to other ethical guidelines. For example, guidelines regarding how the editors should communicate with the authors, especially in sensitive subjects, such as manuscript rejections as there is a considerable variation in authors' research experience. ${ }^{2}$

We recently had an experience of inappropriate behavior of a journal's editor toward us, as manuscript authors, that violated ethical guidelines with no responsibility for their behaviors. We had prepared a manuscript about the psychological issues among people living with the human immunodeficiency virus (HIV) in Iran. HIV is a global pandemic, thus we decided to submit our manuscript to a journal in another continent with the background of published articles from other continents. Then, after 2 days, we received a rejection letter from the editor, which was more about the authors rather than the manuscript (Figure 1). All of these humiliations and offenses were since the editor believed that the manuscript had been submitted to an inappropriate journal as the journal aimed to cover topics related to their continent, which is not anything near a good justification for the editor's behavior, even considering authors' mistake in choosing the appropriate journal. The publisher was contacted to report the editor's behavior and asked to take the appropriate action against such behavior; however, although the publisher initially promised to contact us regarding the editor's email, they did not take any further action, or at least they did not inform us about it.

Such a review process can be considered "rude", as the editor targeted the authors and their country and not the manuscript's content.

\section{1 -Nov-2020}

Dear Dr Nakhostin-Ansari.

Normally this form letter would begin with the statement "Thank you for submitting your manuscript to the Journals Name Sadly I am not minded to begin in this manner. I find it increasingly odd that we are inundated by manuscripts that have nothing to do with AIDS and ConTIRAT NAMF While I am prepared to concede you are at least partly on target, you fail miserably on one of the key criteria. Tehran is a considerable distance from contrastrame. Even the most expansionary visions of our militaristic cosmasrsamer dictators and despots (of whom we still have too many), has not had designs on Iran (your oil perhaps but that is another matter, and indeed another journal).

It is with no regret at all that $i$ urge you to read the remainder of this letter, print it our and laminate it, Then repeat every morning - I will not waste my and editor's time by submitting inappropriate articles.

Unfortunately we cannot consider the above referenced manuscript, entitled "Sleep Disturbance, Psychiatric Characteristics, and Employment Status of People Living with HIV" as only publishes papers that have relevance to HIV/AIDS in Conminen Name contexts.

$\square$ Journal of $\square$ includes articles from, inter alia, the disciplines of sociology, demography, economics, epidemiology, psychology, anthropology, media, health communication, cultural studies, public health, nursing, social development and social work. Papers relating to impact, care, prevention and social planning as well as articles covering social theory and the history and politics of HIV/AIDS will be considered for publication.

Your manuscript may be better suited to one of PUBLISHER'S NAME other journals, but your lack of understanding of basic geography mean you are on your own in finding one.

I would be lying if I signed this 'Sincerely'

Editorial office

Journal

. editor

FIG. 1. Editor's rejection letter

Corresponding author: Amin Nakhostin-Ansari, Research Center for War-affected People, Tehran University of Medical Sciences, Tehran, Iran e-mail: a-nansari@alumnus.tums.ac.ir

Received: October 6, 2021 Accepted: November 1, 2021 Available Online Date: January 18, 2022 • DOI: 10.4274/balkanmedj.galenos.2021.2021-10-23

Available at www.balkanmedicaljournal.org

ORCID iDs of the authors: S.S. 0000-0001-8759-5817; A.H.H. 0000-0003-4607-354X; A.N-A.; 0000-0002-1113-9257.

Cite this article as:

Seifi S, Hoveidaei AH, Nakhostin-Ansari A. Respecting the Authors by Journals' Editorial Team: Doing a Favor or a Responsibility?. Balkan Med J.; $2022 ; 39(1): 76-7$.

Copyright@Author(s) - Available online at http://balkanmedicaljournal.org/ 
According to a study By Jeff C. Clements, $43 \%$ of peer reviews have a minimum of one comment that is unprofessional, and $10 \%-$ $35 \%$ of them have disparaging language. ${ }^{3}$ Such situations happen more to the minority, such as females and non-English speakers and authors from developing countries ${ }^{4}$, and our experience can be an example of such discrimination.

Moreover, negative comments have devastating effects on authors. A study on authors who received negative comments from a journal revealed that $21 \%$ were annoyed and angry, whereas $38 \%$ felt depression and sadness. These types of actions can also cause a loss of confidence and motivation in researchers. Perhaps, if editors consider the author's feelings, such scenarios would be avoided. ${ }^{5}$

To conclude, the author-editor relationship is a complex part of the publishing process and needs to be polite and professional with honesty. The experience we experienced revealed that guidelines are available for editor-author communication; however, these guidelines can be easily disregarded, and supervision is inadequate. Therefore, a gap still occurred between the guidelines and experience in the real world and further actions are needed in this regard.

Author Contributions: Concept - S.S., A.H.H., A.N-A.; Literature Review - S.S., A.H.H., A.N-A.; Writing - S.S., A.H.H., A.N-A.

Conflict of Interest: The authors has no conflict of interest to declare.

\section{REFERENCES}

1. Graf C, Wager E, Bowman A, Fiack S, Scott-Lichter D, Robinson A. Best practice guidelines on publication ethics: a publisher's perspective. International journal of clinical practice. 2007;61:1-26. [CrossRef]

2. Mackiewicz J, Riley K. The technical editor as diplomat: Linguistic strategies for balancing clarity and politeness. Technical communication. 2003;50:83-94. [CrossRef]

3. Clements JC. Don't be a prig in peer review. Nature. 2020;585:472-473. [CrossRef]

4. Grange JA. Time for insulting reviews to stop? Psychologist. 2016;29:158-159. [CrossRef]

5. Majumder K. How do authors feel when they receive negative peer reviewer comments? An experience from Chinese biomedical researchers. European Science Editing. 2016;42:31-35. [CrossRef] 